\title{
Rheology of Liguid Crystals \\ II. Rheological Properties of a Cholesteric Liguid Crystal Mixture
}

by

Tadahiro Asada, Yoshitugu Maruhashi, and Shigeharu ONOGI

(Department of Polymer Chemistry, Kyoto University, Kyoto)

Rheo-optical experiments have been carried out to study the relationship between rheological properties and structure of a typical cholesteric liquid crystal, which is a meltmixed sample of $25 \mathrm{wt}-\%$ of cholesteryl chloride and $75 \mathrm{wt} \%$ of cholesteryl oleyl carbonate. The flow properties and the reflection spectrum of the cholesteric mixture have been measured simultaneously by means of a cone and plate type rheometer combined with a spectrometer at room temperature $\left(27^{\circ} \mathrm{C}\right)$. The flow curve for the cholesteric mixture has the Newtonian flow region at shear rates ranging from $2 \times 10^{-1}$ to $1 \times 10^{2}\left(\mathrm{sec}^{-1}\right)$. At shear rates below $2 \times 10^{-1}\left(\mathrm{sec}^{-1}\right)$, the logarithmic flow curve is a straight line parallel to the ordinate. At shear rates higher than $1 \times 10^{2}\left(\mathrm{sec}^{-1}\right)$, the flow curve concaves upward. The absorbance vs. wave length curve for the cholesteric mixture under shear shows maximum at wave length of around $510 \mathrm{~m} \mu$. The absorbance at longer wave lengths increases with increasing shear rate as long as the flow region is Newtonian. The experimental results obtained can be explained well in terms of orientation of Bragg reflection sites under shear.

\section{液晶のレオロジー的性質 \\ II.コレステリック液晶のレオロジー的性質}

浅田 忠裕・ 丸橋 吉次・小野木重治*

(原稿受理：1975年 2 月26日)

\section{1. 緒言}

われわれは, 先にコレステロール・エステルの液晶状態のレオ ロジ一的性質を研究し122)3)，コレステリック液晶が非常に特異な レオロジー的性質を示すことを知った，更に，このような物質 のレオロジー的性質を解明するためには, どうしても流動光学 (rheo-optics) 的手段を用いた研究が必要であることを指摘した. 本報告では，このような立場からわれわれが新しく開発した流動 光学測定装置と，この装置を用いたコレステリック液晶の流動性 に関する研究の一例を報告する。

\section{2. 液体および液晶用の新しい流動光学測定装置の 試作 \\ 既報 ${ }^{4)}$ のンオメーター（島津 RM-1 形）のステンレス製コーン \\ * 京都大学工学部 京都市左京区吉田本町}

・プレートを石英製のもので置き換え, これに分光光度計を接続 し, 定常的せん断変形あるいは動的せん断変形を受けている試料 の透過光のスペクトルを定量的に測定できるようにした．最初に 試作した石英製コーン・プレートのコーン角は $3.85^{\circ}$, 直径は 80 $\mathrm{mm}$ である. あらかじめこの石英製コーン・プレートを用いて粘 度標準液掞よび動的粘弾性の諸量が既知の高分子濃厚溶液の定常 流粘度拈よび動的粘弾性を測定し，レオメーターとして正常に作 動することを確認した．用いた分光光度誩（島津マルチコンバー ヂブル分光光度訫D 40形) は単光束形のものであるが，ブランク 測定で光束を検知器に達せしめたのち, ただちに試料透過光の光 束を検知器に達せしめると, 自動的に透過率を測定できるように なっている.この分光光度計の試料室を改造して, ハンドルの回 転で $45^{\circ}$ 回転するミラーを取り付け，このミラーを回転すること により, ブランクの光束と試料透過光束が交互に検知器に達する ようにした。 


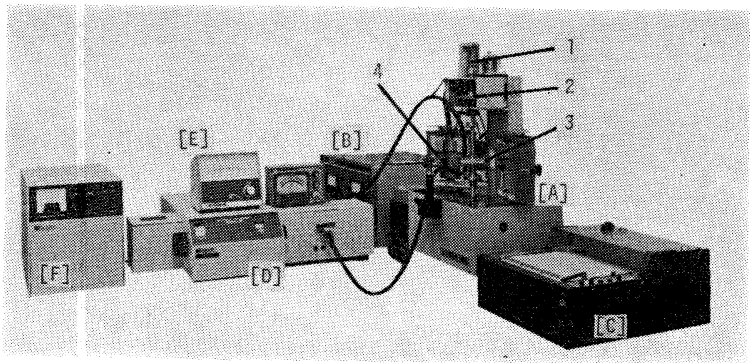

Fig. 1. Rheo-optical apparatus. A; Rheometer, B; Controller for rheometer, C; Recorder for torque, D;Spectrophotometer, E; Optical density meter, F; Controller for spectrophotometer. 1; Torsion wire, 2; Differential transducer, 3; Quartz cone and quartz plate, 4; Supporting arm for light guides.

試作した新しい流動光学測定装置の全容を Fig. 1 亿示す。図 中 $[\mathrm{A}],[\mathrm{B}],[\mathrm{C}],[\mathrm{D}],[\mathrm{E}]$ 拈よび $[\mathrm{F}]$ は, それぞれ従 来のレオメーター本体, レオメーター制御部, トルク龍録用レコ 一ダー, 分光光度計本体, 吸光度メーターおよび分光光度諳堌 部である，また，(1)，(2)，(3)及び(1)はそれぞれトーション・ワイ ヤー,トルク検出用差動トランス, 石英製コーン・プレート, お。 よびライト・ガイドの支柱である，この流動光学測定装置の原理 図を Fig. 2 に示す. 光源 (A) から発した光はモノクロメータ 一部 (B) で分光され, 出口スリットから出て, 試料室 (C) に 入る. この光束はミラー $(\mathrm{m})$ を $45^{\circ}$ に傾けたとき, ライト・ガ イド（グラスファイバー管，D）に入射され，これに誘導されて， プレートの下側から試料に入射される. ミラー $(\mathrm{m})$ を元の位置 にもどした場合は, 光束は淔進して, 標準光束として探知器 (I) に直接達する.プレート (E), 試料 $(\mathrm{F})$, コーン $(\mathrm{G})$ を透過 した光束はライト・ガイド $(\mathrm{H})$ で受けられ, 標準光束と比較さ れて,メーター（K) の指針を作動させる。メーター（K) には透 過率または吸光度として示される。な拈，ライト・ガイド $(\mathrm{D}, \mathrm{H})$ の有効断面は直径 $10 \mathrm{~mm}$ の円形であり, 個々の繊維の直径はこ0, $\mathrm{u}$ である，一方，試料にせん断変形を与えるとさに生じるトルクは， 差動トランス (M) で検出され, 增幅器 (Y) で増幅され, レコ 一ダー $(\mathrm{P})$ ，または $(\mathrm{Q})$ の 側のペンで記録される。また，動 的せん断変形を与えたときの变形は, 下側の差動トランス $(\mathrm{N})$ で検出され, 増幅器 (X) を介してレコーダー $(\mathrm{P})$, または (Q) のX側に記録される。

\section{3. 実}

\section{験}

(i) 測定

液晶試料に波長 450 から $700(\mathrm{~m} \mu)$ の単色光を順次入射し，透 過率を測定した。入射光はプレートの面に垂直に入射するょうに し，受光側ライト・ガイドの受光面もこれに合わせた．今の場合， 用いた試料と石英の屈折率はほ涪等しいので，コーン面の傾斜を 考虑した光の屈折による補正は無視しらる程度である.光の透過 率の測定は, 光学軸がコーン・プレートの軸から $3.0 \mathrm{~mm}$ の位置 を通るようにして行った (Fig. 2 参照)。な扐, 透過率測定の場 合には，関係部分をすべて瞕室に内蔵した。すべての波長の光に ついて，(グラスファイバー+石英製 コーンプレート）の透過率 を測定し，これを $100(\%)$ ラインとして，試料の吸光度を算出し た.

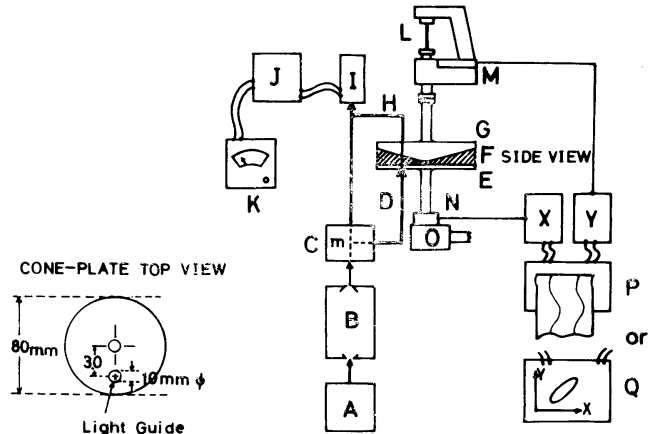

Fig. 2. Block diagram of Rheo-optical Apparatus I. [Optical system]

A;Light source, B;Monochromator, C;Sample chamber, $\mathrm{m}$; mirror, D; Glass fiber tube (light guide, $10 \mathrm{~mm} \phi / 30 \mu$ ), E; Quartz plate, F;Sample, G; Quartz cone, $\mathrm{H}$; Glass fiber tube, I; Photomultiplier tube, J; Amplifier, R; Optical density meter.

[Mechanical system]

$\mathrm{L}$; Torsion wire, M;Differential transducer for detecting torque, $\mathrm{N}$;Differential transducer for detecting applied strain, $\mathrm{O}$; Gear box, $\mathrm{X}, \mathrm{Y} ;$ Amplifier, $\mathrm{P} ; 2$ pen recorder, $\mathrm{Q} ; \mathrm{X}-\mathrm{Y}$ recorder.

試料をコーン・プレートの間に装てんし，温度を約 $60^{\circ} \mathrm{C} に し て ，$ 等方性液体に30分間保ち，その後室温まで放冷して30分以上経過 後, 種々の波長の光に対する処女試料の透過光強度を測定し，続 いてプレートを一定の角速度で回転し, 㭘出トルクをレコーダー に記録した。トルクが一定值に達した定常状態に执いて, 試料の 透過光のスペクトルを測定した．種々のせん断速度で測定する場 合には，常に低いせん断速度から測定を始め，順次段階的にせん 断速度を上げて測定した。また，このほかに回転を停止したのち 試料の透過光スペクトルの変化をも観測した，本報告に示す結果 は，すべて室温 $\left(27^{\circ} \mathrm{C}\right)$ で測定でたものである，せん断速度 $(\dot{\gamma})$ はプレートの回転角速度 $(\omega)$ とコーン角 $(\alpha)$ から, 式 $\dot{\gamma}=\omega / \alpha$ [ $\mathrm{sec}^{-1}$ をを用いて算出した。

(ii) 試料

コレステリック液晶のモデル試料として, cholesteryl chloride (メルク社製) と cholestesteryl oleyl carbonate (メルク社製) と を重量比で 25:75 の割合で溶融混合した混合物を用いた。これ らのコレステロール誘導体の混合物は, 成分の混合比を変えるこ とによって, コレステリック液晶構造の 分子平板の 分子軸方向 (director) のらせん回転の周期（以下，らせんのピッチと略称す る）を変化させることができ, 特にこの混合比では, 常温で可視 光の範团の光を選択反射することが知られている ${ }^{6)}$ ので, この物 質をモデル試料として選んだ.

\section{4. 理 論}

コレステリック液晶は, 特定波長の光を選択反射することによ って，コレステリック液晶に特徽的な様々な色を呈する. 入射光 が光軸（コレステリック周期構造のらせん軸）に対して，ある解 度をもつ場合には，反射光のスペクトルは，入射角 $\phi_{i}$ のみなら ず散乱角 (反射角) $\phi_{s}$ にも依存する (Fig. 3 参照). Fergson ${ }^{5)}$ は， コレステリック液晶の選択反射に対してBragg の反射の考え方を 適用して，最大反射強度を与える光の波長 $\lambda_{M}$ と，コレステリッ 
ク構造のらせんのピッチ $P$ との間に次の式を導いた.

$$
\lambda_{M}=2 n P \cos \frac{1}{2}\left[\sin ^{-1}\left(\frac{\sin \phi_{i}}{n}\right)+\sin ^{-1}\left(\frac{\sin \phi_{s}}{n}\right)\right]
$$

ここで $n$ は液晶の平均の屈折率である。

Adams ら ${ }^{6}$ はコレスリック液晶のフィルムの光学的性質を測定 し, その結果に対して Fergason の考方方が適用できることを示 した。すすなわち，未変形のフィルムでは，Fig. 3 に示すよ5な

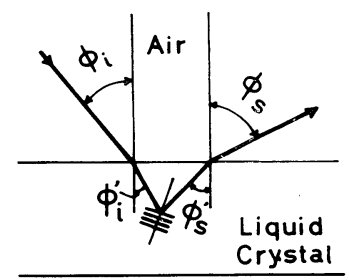

Fig. 3. Geometry for dispersive reflection.

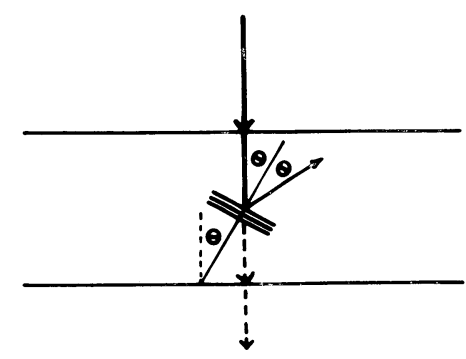

Fig. 4. Helical screw axis of a cholesteric Bragg site is at angle $\theta$ from the normal. Incident, reflected, and transmitted light shown by arrows.

Bragg の反射要素がランダムに分布していて，一定の変形を加え たとき，この Bragg の反射要素（以下，Bragg 要素と略記する) が配向すると考えると，これらのフィルムの光学的挙動が説明で きることを示した．ここでは，このような考方方に基づいて，せ ん断力を受けたコレステリック液晶の光学的挙動を解橎しょうと 寸るものである．いま Fig. 4 亿示されているように，光軸が入 射光に対して $\theta$ の角度をなしている Bragg 要素を考学る．この Bragg 要素のらせんのピッチPは次式で与えられる.

$$
\lambda_{m}=2 n P \cos \theta
$$

ここで, $\lambda_{m}$ は透過光のうち最小強度を与える光の波長である. $n$ は媒体の平均の屈折率である。試料が Grandjean texture と呼 ばれる層状構造をもつときは, 試料中のすべての要素について $\theta$ $=0$ である. このとき, 最大反射強度（ないしは最小透過強度） を与光る波長は， $\lambda_{0}=2 n P$ である．このとき， $P=\frac{1}{2 n} \lambda_{0}$ はこの Grandjean texture のらせんのピッチである. $\theta \neq 0$ のとき, 最小 透過強度は $\lambda_{0}$ より少し異なった波長 $\lambda て ゙$ 観測されるはずである. いま，考えている Bragg 要素のらせんのピッチPは，

$$
P=\lambda_{0} / 2 n
$$

であると仮定し, この要素がせん断力を受けて特定の力向に向い ていて, その光軸が光の入射方向と $\theta$ の角度をなすとすると, 最 小透過強度を与える光の波長 $\lambda$ はせん断速度 $(\dot{\gamma})$ の関数として表 されるであろらから，これを $\lambda(\dot{\gamma})$ と記すと，

$$
\lambda(\dot{\gamma})=2 n P \cos \theta=\lambda_{0} \cos \theta
$$

で与えられるはずである．したがって，要素の光軸が入射光の方 向となす解 $\theta$ は,

$$
\theta=\cos ^{-1}\left[\lambda(\dot{\gamma}) / \lambda_{0}\right]
$$

で与えられるはずである。

われわれは，これらの関係を基にして，実験結果を解釉しょう とするものである. 式（3）の仮定は，せ九断力が加わっても， コレステリック構造のらせんのピッチ $P_{0}$ は変化を受けず, Bragg 要素の向きだけが変化することを意味する。また，式（4)，(5) は属折率 $n$ の媒体中にあるただ一つの Bragg 要素について算出さ れたものであり，実際の試料では多数の Bragg 要素を考えねばな らないので，配向の一様な場合についてだけ適用できるものであ る. 実際のデータを解釈する場合には Bragg 要素の配向分布を考 えねばならないし，さらに 2 次以上の散乱の効果を考虑する必要 があると思われる。

\section{5. 結 果と考 察}

まず, 試料のレオロジ一的応答について, 続いて光学的挙動に ついて述ベ，最後に両者の関係を検討する.

コーン・プレートの中で溶融状態から, ゆっくり温度を下げ, 室温にもたらした試料（以下，これを処女試料と呼ぶ）に一定の せん断速度 $(\dot{\gamma})$ の変形を与兄る之，せん断応力 $(\sigma)$ はせん断変 形（以下，变形と記す）している時間 $(t)$ によって変化する。 こ のような例を Fig. 5 に示す.すなわち, 高いせん断速度では,

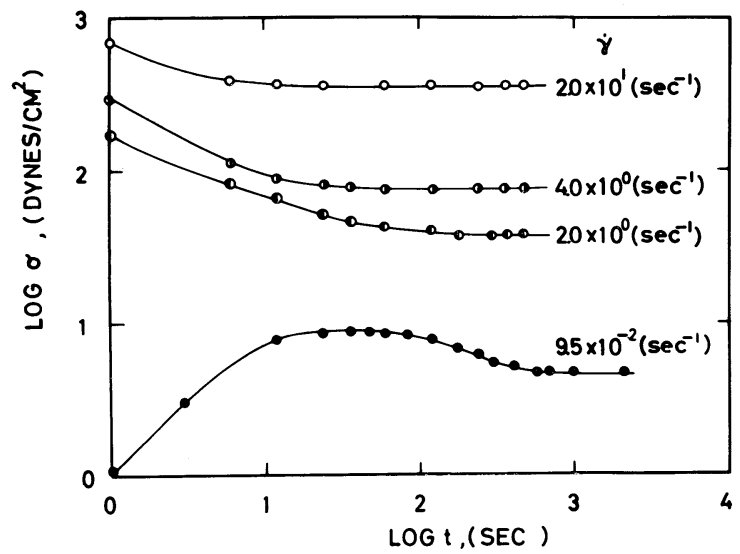

Fig. 5. The change in shear stress $(\sigma)$ in the time course of approaching to the steady state at various shear rates.

最初大きい応力を示すが, 応力は時間と共に低下し, 次第に一定 值 $\sigma_{e}$ に近づく (以下, 定常状態の応力を $\sigma_{e}$ と記す). しかし, 低いせん断速度では, 図から明らかなように, 応力はいったん增 加して極大をとったのち，次第に一定值に近づく．既に低い字で 测定した試料に，更にそれより高い $\dot{\gamma}$ の変形を与えて得られた

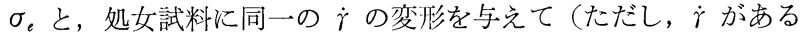
程度大さい範囲で）得られる $\sigma_{e}$ とは流涪一致することが分かっ たので，低い方から測定を開始し，順次段階的にせん断速度を高 めて行き，種々の定せん断速度の下で $\sigma_{e}$ を測定した。 $\dot{\gamma}$ と $\sigma_{e}$ の 関係，すなわち流動曲線を Fig. 6 に示す。この図の黑丸は, 同 一の宁で処女試料について得られた值である。また太い実線は勾 配 45 のの直線である。この図から明らかなように, $\log \dot{\gamma}$ と $\log \sigma$ 。 


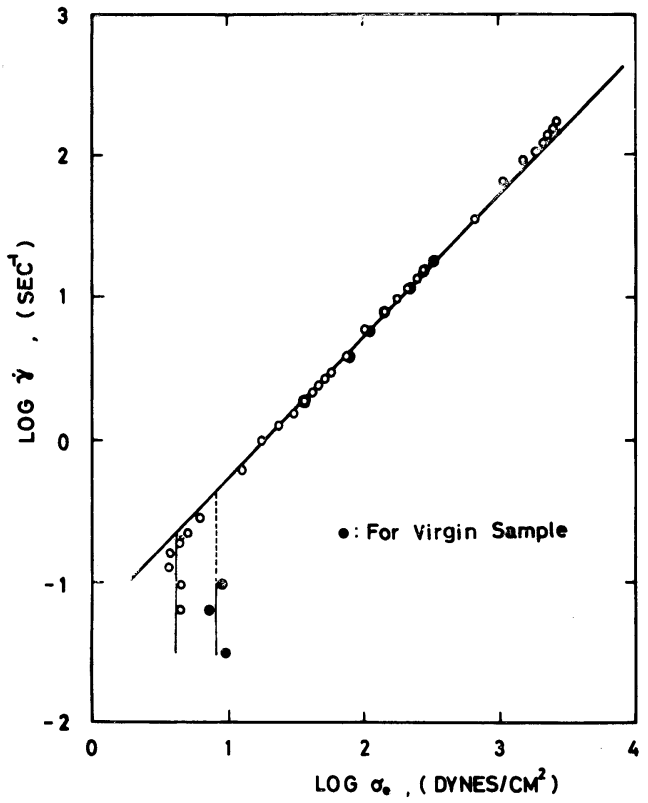

Fig. 6. Log-log flow curve for a typical cholesteric liquid crystal.

の関係は, $\dot{\gamma}$ が中程度の $2 \times 10^{-1}\left(\mathrm{sec}^{-1}\right)$ から $1 \times 10^{\prime}\left(\mathrm{sec}^{-1}\right)$ の範 因では $45^{\circ}$ の直線汇ほぼ一致する。この領域を便宜上, ニュート ン領域と呼ぶことにする. $\dot{\gamma} \div 2 \times 10^{-1}\left(\mathrm{sec}^{-1}\right)$ 以下のせん断速度 では, 縦軸にほぼ平行な直線で近似され, この液晶の流動曲線は ビンガム的である.

次に, 透過光のスペクトルのせん断速度による変化について述 ベる. 処女試料の吸光度スペクトルを Fig. 7(a), (b) に実線で 示す。また，種々のせん断速度の下で，。。を得た時点に扣ける 試料の透過光の吸光度スペクトルを Fig. 7(a), (b) に示寸. 図 から明らかなように, 処女試料 (未変形) においては, 測定した 波長範囲, すなわち 450 700 $\mathrm{m} \mu$ では, 特定波長に拈ける吸光度 に極大は見られず, $550 \mathrm{~m} \mu$ 付近から吸光度は急に減少する。こ れに対して，試料にせん断変形を与えている場合には，500～550 $\mathrm{m} \mu$ 付近に吸光度の極大がはっきり認められる. 吸光度の極大を 与える波長 $\lambda_{m}$ は, せ九断速度によって多少変化する程度である
が, ニュートン領域に属するせん断速度の下では, 吸光度曲線の 長波長側の肩がせん断速度が增す注ど，長波長側へせり出す傾向 がはっきり認められる。

Adams $5^{5)}$ は，われわれが用いたのと同じ液晶で混合比が異な る種々の系の未変形および変形皮膜について散乱光スペクトルの 入射角执よび反射角汶詨する角度分布を詳しく測定し，その結果 を Fergason の式 (1) でュンピューター・フィットさせ，変形皮 膜に怙いては, 変形によって各Bragg 要素の配向は変化するが, コレステリックのピッチPは変化しないと報告している．彼らの 報告では, 変形量は定量的に示されていないが, その記述内容か ら, 試料に大変形を与えたことが推察される. 彼らの見解をわれ われの場合にも準用し, 且つ式 (4)を考慮すると, 上述の上5に, せん断速度が增大寸るほど長波長成分の吸光度が増大するのは, 試料中に分布している Bragg 要素の分子平板面がせん断力によっ てプレート面に平行な方向に向かって配向すること，そしてその 配向の程度はせん断力が大きいほど大きくなることを暗示してい る.すなわち, ニュートン領域では, せん断力によって Bragg要 素が配向することを示している.

高せん断速度側の非ニュートン領域に扮ける試料の光学的性質 は，それ以下のせん断速度に打ける性質と全く異なり，絹系のよ らにキラキラ輝いた光沢を呈し, 明らかに高度の光散乱を示す液 晶となる。

一定のせん断速度で応力が定常值に達してのち, せん断を停止 すると, 応力は速やかに 0 飞復帰するが, 透過光のスペクトルは 回転停止後も時間と共に変化し, もっと鋭い吸光度の極大を示す 図形に変化して行く. これは, コレステリック液晶の Bragg 要素 の配向がせん断停止後も著しく進行することを示すものと考兄ら れ, 注目に值する現象である. 上述のようなスペクトルの経時変 货は, 与えたせん断速度が低周波数側の非ニュートン域である場 合にはそれほど顕著ではなく、ニュートン域ではせん断速度が高 いほど顕著である，経特変化の一例を Fig. 8 飞示す，この図に 示されているのは, 比較的高いせん断速度を経験した試料の場合 である。

Pochan7) らは，パイレックス・ガラスを円板とする平行円板 型レオメーターを用い, われわれと同様, せ九断変形下の透過光 スペクトルの測定を行っているが，彼らが zero shearとして示し

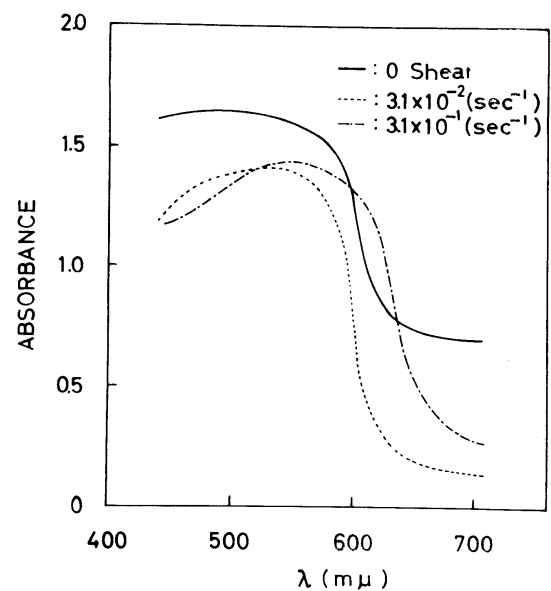

(a)

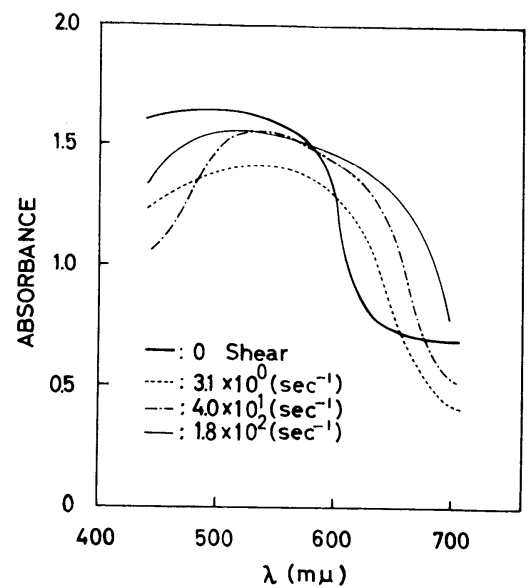

(b)

Fig. 7. Optical density as a function of wavelength for various shear rates. 


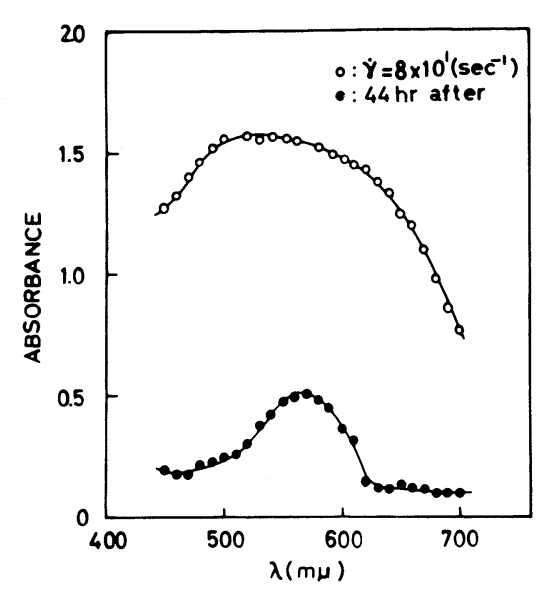

Fig. 8. An example of relaxation of spectra with time, after shear.

$\circ$;Under shearing at $8 \times 10 \mathrm{sec}^{-1}$.

- ; $44 \mathrm{hr}$. after shearing at $7 \times 10 \mathrm{sec}^{-1}$.

ている試料のスペクトルは, 本報の Fig. 8 に示した過去にせん 断を受け，その後放置した試料のそれに全く酷似して抢り，彼ら
の実験では何らかの理由により最初から高度に配向した系を出発 試料としている点が, 本研究と根本的に異なる点である。

（昭和49年10月 3 日，第22回レオロジー討論会で講演）

\section{文献}

1）浅田忠裕, 田口雅明, 小野木重治, 日本レオロジー学会誌, 2, 66 (1974).

2) Asada, T., Y. Maruhashi, and S. Onogi, "Vth Intern. Liquid Crystal Conference, Abstracts", 33 (1974), Stockholm.

3) Asada, T., Y. Maruhashi, and S. Onogi, J. De Physique, 36, 305 (1975).

4) 葛谷道夫, 材料, 22, 424 (1973).

5) Fergason, J.L., Mol. Cryst., 1, 293 (1966).

6) Adams, J.E., W. Haas, and J. Wysoki, J. Chem. Phys., 50, 2459 (1969).

7) Pochan, J.M., D.G. Marsh, J. Chem. Phys., 57, 1193 (1972). 